\title{
The Multidimensional Constructs of Organizational Justice and Organizational Commitment: Empirical Evidence From Public and Private Organizations in Indonesia
}

\author{
Fahrudin JS Pareke ${ }^{1 *}$ \\ ${ }^{1}$ University of Bengkulu, Bengkulu, Indonesia
}

\begin{abstract}
The multidimensional construct of organizational justice and organizational commitment has attracted longstanding attention and debate among managers, researchers and academicians. To achieve significant progress, studies in this area should be directed to investigate the two sides simultaneously, construct validity and substantive validity. So that the progress achieved can be balanced between the conceptualization and definition of the construct itself as well as the relationship and its effect on other constructs. Therefore, current study intents to test the validity dan reliability of four-factors of organizational justice (FFOJ) construct, and to test its effect on organizational commitment dimensions. The research respondents were 264 private employees and civil servants who studying in 3 graduate programs at University of Bengkulu, choosen using stratified random sampling. Two-hundred-and-fifty-seven respondents participated in the study. Data analysis used Factor Analysis, reliability test, and Hierarchical Regression Analysis (HRA). The conclusions of this study provide strong support for the FFOJ conceptualization. Of the 20 items questionnaire included in factor analysis, 19 items loaded in 4 dimensions, which is distributive justice (4 items), procedural justice (6 items), interactional justice (4 items), and informational justice (5 items). The reliability of all dimension are good, with Cronbach 'Alpha $(\alpha)$ score greater than 0.7. Almost all dimensions of FFOJ affect the dimensions of organizational commitment, except the interactional justice that has no effect on the affective commitment. Further investigation is highly recommended so that organizational justice measurement becomes more workable in explaining the phenomena of justice in the daily life of the organization. The empirical evidence also further emphasized the important role of organizational justice in order to foster, enhance, and maintain organizational commitment. Attempts to acquire employees with high organizational commitment will face serious obstacles when the employees still perceive there is no fairness in their organization.
\end{abstract}

Keywords: afective commitment, continuance commitment, distributive justice, interactional justice, informational justice; procedural justice, normative commitment

\footnotetext{
* Corresponding author. Email address: pareke@unib.ac.id
} 


\section{INTRODUCTION}

The aspects of justice is very important in the dayly life of the organization, given the consequences that can occur if employees perceive the existence of injustice. For example, if an organization or its representatives perceived to be unfair, members of the organization will have low organizational commitment and OCB (Skitka and Bravo, 2005). Skitka and Bravo (2005) also found that injustice will encourage crime in the workplace and the desire to protest. It is not surprisingly, the issues relating to justice become the most attractive issue for everyone in the organization (Sert, et al., 2014). Organizational justice, therefore, is an issue that needs serious attention (Azizi and Zulkiflee, 2016). As Greenberg (2001) stated, everyone believes that to be fair depends on generally agreed opinions on appropriate ways to distribute results and ways of treating others. This general agreement is the origin of expectations on which to estimate fair treatment. Behaviors that meet these expectations are interpreted as fair action, while those that violate expectations are considered unfair.

Initial debate on organizational justice emphasised on the aspect of distributive justice, but lately the perspective of procedural justice is increasingly being studied (Folger and Konovsky, 1989). According to Chan (2000) distributive justice can be defined as a perception of fairness about results or resources allocation. The procedural justice aspect deals with the procedures by which the organization distributes organizational results and resources to its members. Folger and Cropanzano (Chan, 2000) define procedural justice as equity issues relating to the methods, mechanisms, and processes used to determine outcomes.

In recent studies, the concept of organizational justice has undergone a very rapid development, by promoted of a new dimension of organizational justice, interactional justice. Interactional justice relates to the interaction between organization members with its refresentatives. The informational justice proposed by Colquitt (2001) as a fourth dimension, relating to the access and transparency of information within organizations. The Colquitt's (2001) FFOJ conceptualization has been used and tested extensively in various settings and countries (Dfaz-Gracia et al., 2014; Kovacevic at al., 2013; Shibaoka et al., 2010). This research stream basically tried to investigate the construct validity aspect, conceptualization and definition of construct of organizational justice. These research stream is important, as it seeks to minimized obstacles to the development of the body knowledge and literature in this field over the long term. In particular, to eliminate difficulties in understanding the patterns contained in the empirical literature in this field (Podsakoff et al., 2000).

Other research streams focused more on the substantive validity, to explain the pattern of relationships between organizational justice and other constructs, such as job satisfaction, OCB, and organizational commitment. Organizational commitment is one form of employee work attitude that affected by organizational justice. Greenberg and Baron (2000: 170) defined attitudes as the clusters of feelings, beliefs and tendencies of relatively stable behavior (eg tendency toward certain objects). One's attitude in working life in organizational behavior literature is called work-related attitudes, which included job satisfaction (attitude toward work) and organizational commitment (attitude toward the organization). Organizational commitment in general is employee's involvement and identification with a particular organization (Clugston, 2000). 
The explanation and verification of the effect of organizational justice on organizational commitment is done through theories, as well as empirical studies. Conceptually, some theories have been proposed to explain the phenomena of the relationship among perception of justice, attitudes and behavior. Among them are Social Exchange Theory (SET), Leader-Member Exchange (LMX), and Equity Theory (ET). SET is an economical model of human behavior; an employee's desire to maximize rewards and minimize losses that support the interaction between them and the organization or those who represent it. This model has a premise on beliefs about the social context of the organization, including relationships based on mutual trust and interaction, carrying non-specific obligations (Wat and Shaffer, 2005). These obligations can take the form of a work attitude such as organizational commitment. Employees portray this behavior to maintain a mutually beneficial relationship with the organization. As time passes, a pattern of reciprocal relations evolves, resulting in a perception of a balance in an exchange relationship. When the responsible party is identified, according to the SET, individuals develop a desire to provide feedback, leading to the creation of shared obligations in a relationship (Murphy et al., 2003).

LMX theory argues that leaders do not build a same relationships with their subordinates. For some of their subordinates, leaders formed a better quality of exchange characterized by trust, affection, and respect. While with some other subordinates the leader formed a lower quality of exchange, that includes only the interactions required by the definition of a person's role (Murphy et al., 2003). Lower quality exchange is characterized by the use of formal organizational authority. While higher quality relationships involve the exchange of resources beyond those listed in formal employment contracts. Therefore, employees are more likely to demonstrate organizational commitment if they work in a fair organization and have a high quality relationship with their supervisors (Wat and Shaffer, 2005).

Conceptual explanations of the relationship between employees' perceptions and attitudes also found in Equity Theory, which promotes that individuals are motivated to maintain fairness of relationships between them, and avoid unfair or unnatural relationships (Greenberg and Baron 2000 ). According to Equity Theory, employees will feel very satisfied when the ratio between their benefits received with contributed is proportional to the ratio of their peers. If employees perceive they are treated fairly by their supervisors, they will tend to reward them by showing a positive attitude toward their work, work performance, and commitment.

Efforts for providing the empirical evident of the literatures of organizational justice on commitment have been made through empirical researches (such as Srivastava, 2015, Rafei-Dehkordi, 2013; Jawad et al., 2012; Davis \& Rothstein, 2006; Hassan, 2002; Aquino, 1997; Pareke, 2004; Pareke, 2003). However, previous studies have not generally proven the effect of each dimension of organizational justice on each dimension of organizational commitment as a whole. Rafei-Dehkordi (2013) and Jawad et al. (2012) for example, examines only three dimensions of organizational justice (distributive, procedural, and interactional) on organizational commitment without specifying its dimensions. Pareke (2005) concluded that distributive justice affects affective and normative commitment, and procedural justice affects continuance and normative commitment. 


\section{METHODS}

\section{Respondents}

The total respondents was 264 people, who were the private employees and civil servants currently studying in 3 graduate programs at Faculty of Economics and Business, University of Bengkulu, Indonesia. Samples were chosen using Stratified Random Sampling method, where the population will be grouped based on the study program, then from each group will be taken some random samples. Of the 264 selected respondents, only 257 respondents participated in the study. The demographic composition of respondents was $61.1 \%$ male; $65,3 \%$ were between 26 to 40 years old; $59,9 \%$ had a tenure under 11 years; and $77.8 \%$ worked at government institutions.

\section{Measures}

Organizational justice measured by adopting Colquitt (2001)'s conceptualization, consisting of four dimensions, distributive justice, procedural justice, interactional justice, and informational justice. Using 20 item statements measured by Semantic Differential Scale, score $1=$ never up to $5=$ always (Sekaran, 2000: 198-199). Organizational commitment measured by Alen \& Meyer (1990), consisted of affective, continuance, and normative commitment. Each dimension consists of 6 items, using a 5-point Likert scale, 1 = strongly disagree to $5=$ strongly agree.

\section{Analyses}

Data analysis was done in 3 stages, first to re-verify the dimensions of organizational justice using Factor Analysis. Principal Component Analysis was applied to transform all items into a set of group variables that are not correlated with each other (Sekaran, 2000: 409). The factor rotation method used was the VARIMAX Rational Approach, where maximum simplification is possible if there are only 1 and 0 in a column. The VARIMAX method maximized the amount of variance by loading required from the factor matrix. With the VARIMAX approach, it will tend to show some high loading (ie close to -1 or +1 ) and some loading close to 0 in each column of the matrix (Hair et al (1998: 109-110) .VARIMAX tends to provide a separation of factors more clearly. In addition, further data analysis to test the level of reliability, by summing the Cronbach 'Alpha $(\alpha)$ score.

Furthermore, the Hierarchical Regression Analysis (HRA) applied to examine the effect of FFOJ dimensions on each dimension of organizational commitment. Using the 2 steps approach at 3 models of regression (depends on the number of dependent variables). In the first step, the control variables (gender, age, tenure, job level, organization type) as independent variables were reggressed on dependent variable. In the second stage, the FFOJ dimensions (distributive, procedural, interactional, and informational) were included as independent variables, after inputting the control variables first. To evaluate the regression model, the parameter used was the $F$ value, with the model criterion to be considered good if the probability value $(\rho$ value $) \leq 0.05$. To conclude whether the dependent variable had an effect on the independent variable, the parameter used was the value of beta value $(\beta)$, with the criterion of the dependent variable having an effect on the independent variable if the probability value $(\rho$ value $) \leq 0.05$. 
The Multidimensional Constructs of Organizational Justice and Organizational Commitment: Empirical Evidence From Public and Private Organizations in Indonesia

\section{Result of Factor Analysis of Organizational Justice}

Factor analysis to the 20 FFOJ items with Varimax rotation method, resulting 5 factors/components. As table 1 shows, the first factor was able to explain $30.95 \%$ of the data variance. The second factor explained $11.43 \%$ of the data variance. The third factor explained $8.33 \%$ of the data variance. And the fourth factor was able to explain $6.77 \%$ data variance. Table 1 also shows the total variance explained by four factors of FFOJ, reaching 57, $48 \%$.

Table 1 Persentase of Total Variance Explained

\begin{tabular}{cccc}
\hline \multicolumn{4}{c}{ Total Variance Explained } \\
\hline & \multicolumn{3}{c}{ Initial Eigenvalues } \\
\cline { 2 - 4 } Component & Total & \% of Variance & Cumulative \% \\
\hline 1. & 6.190 & 30.948 & 30.948 \\
2. & 2.286 & 11.430 & 42.378 \\
3. & 1.665 & 8.326 & 50.705 \\
4. & 1.354 & 6.769 & 57.474 \\
\hline
\end{tabular}

Extraction Method: Principal Component Analysis.

Table 2 shows the factor loading of each item FFOJ that have score above 0,4. The first factor, referring to the Colquitt (2001) conceptualization, is procedural justice. Initially, this dimension had 7 statement items, however, in this study reduced to 6 items. One item, which is "I have been able to appeal the outcomes arrived at by those procedures" formed another factor (factor 5), so it does not fit into this factor. Factor 2, referring to the informational justice dimension, has 5 statements. Factor 2 dan 4, referring to the interactional dan distributive justice dimension, has 4 statements. While the fifth factor has only 1 item. 
Table 2 Rotated Component Matrix

\begin{tabular}{|c|c|c|c|c|c|c|}
\hline \multirow{2}{*}{ No. } & \multirow{2}{*}{ Items } & \multicolumn{5}{|c|}{ Component } \\
\hline & & 1 & 2 & 3 & 4 & 5 \\
\hline & My outcome reflect the effort I have put in to my work & & & & .741 & \\
\hline & My outcome appropriate for work I have completed & & & & .670 & \\
\hline & My outcome reflect what I have contributed to the organization & & & & .768 & \\
\hline & My outcome justified, given my performance & & & & .718 & \\
\hline & $\begin{array}{l}\text { I have been able to express my views and feelings during those } \\
\text { procedures }\end{array}$ & .595 & & & & \\
\hline & I had influence over the outcome arrived at by those procedures & .672 & & & & \\
\hline & Those procedures have been applied consistently & .754 & & & & \\
\hline & Those procedures have been free from bias & .754 & & & & \\
\hline & Those procedures have been based on accurate information & .623 & & & & \\
\hline & $\begin{array}{l}\text { I have been able to appeal the outcomes arrived at by those } \\
\text { procedures }\end{array}$ & & & & & .748 \\
\hline 11. & Those procedures upheld ethical and moral standards & .457 & & & & \\
\hline 12. & He/She has treated me in polite manner & & & .721 & & \\
\hline 13. & He/She has treated me with dignity & & & .818 & & \\
\hline 14. & He/She has treated me with respect & & & .721 & & \\
\hline 15 . & He/She has refrained from improper remarks or comments & & & .708 & & \\
\hline 16. & He/She has been candid in his/her communications with me & & .688 & & & \\
\hline 17. & He/She has explained the procedures throughly & & .635 & & & \\
\hline 18. & His/her explanations regarding the procedures reasonable & & .706 & & & \\
\hline 19. & He/She communicated details in timely manner & & .701 & & & \\
\hline & $\begin{array}{l}\text { He/She has seemed to tailor his/her comunications to individual } \\
\text { specific needs }\end{array}$ & & .549 & & & \\
\hline
\end{tabular}

\section{Reliability Test of Organizational Justice and Commitment Dimensions}

Table 3 shows the results of reliability testing using Cronbach's Coefficien Alpha $(\alpha)$. The goal was to know the level of consistency of the interitem, reflecting the consistency of respondents in response to all question items. Respondents may not be consistent in answering items of questions due to differences in perceptions, or because of their lack of understanding of the items. Reliability testing was performed for each dimension. Although some researchers recommend a level of reliability of not less than 0.8 , yet a degree of reliability above 0.7 is still acceptable (Ko et al., 1997). According to Sekaran (2000), the $\alpha$ coefficient value of less than 0.6 means the reliability is bad, range 0.7 is acceptable, and more than 0.8 is good. All FFOJ dimensions and organizational commitment were above 0.7 , indicating that all dimensions considered reliable. 
The Multidimensional Constructs of Organizational Justice and Organizational Commitment: Empirical Evidence From Public and Private Organizations in Indonesia

Table 3 Results of Reliability Tes

\begin{tabular}{clcc}
\hline No. & \multicolumn{1}{c}{ Dimensions } & Total Item & Cronbach's Alpha \\
\hline 1. & Distributive Justice & 4 & .712 \\
2. & Procedural Justice & 6 & .808 \\
3. & Interactional Justice & 4 & .816 \\
4. & Informational Justice & 5 & .827 \\
5. & Affective Commitment & 6 & .757 \\
6. & Continuance Commitment & 6 & .761 \\
7. & Normative Commitment & 6 & .779 \\
\hline
\end{tabular}

\section{Descriptive Statistics}

Table 4 presents the mean, standard deviation, and zero-order correlation. The means for all research variables are above the median. These data indicate that the respondents reported a high level of organizational justice and organizational commitment. The correlation between each control variable (sex, age, level of position, type of organization) is good, with correlation coefficients ranging from 0.107 to 0.483 . Similarly, the level of correlation between each dependent variable and independent is very good, ranging from 0.265 to .786 . While the correlation between each control variable with independent and dependent variable is low, ranging from 0.008 to .104. This correlation level indicates the expected direction.

Tabel 4 Means, Standard Deviation, and Zero-order Correlations

\begin{tabular}{|c|c|c|c|c|c|c|c|c|c|c|c|c|c|c|}
\hline & Variables & Means & s.d. & 1 & 2 & 3 & 4 & 5 & 6 & 7 & 8 & 9 & 10 & 11 \\
\hline 1. & Gender & .61 & .488 & & & & & & & & & & & \\
\hline 2. & Age & 35.35 & 7.808 & $.182^{* *}$ & & & & & & & & & & \\
\hline 3. & Tenure & 10.05 & 7.131 & $.175^{* *}$ & $.937^{* *}$ & & & & & & & & & \\
\hline 4. & Job Level & 1.22 & .416 & -.112 & $-.227^{* *}$ & $-.183^{* *}$ & & & & & & & & \\
\hline 5. & $\begin{array}{l}\text { Organization } \\
\text { Type }\end{array}$ & 1.56 & .617 & $.182^{* *}$ & $.483^{* *}$ & $.453^{* *}$ & .107 & & & & & & & \\
\hline 6. & $\begin{array}{l}\text { Distributive } \\
\text { Justice }\end{array}$ & 13.0311 & 2.86939 & -.039 & -.103 & -.105 & .020 & .089 & & & & & & \\
\hline 7. & $\begin{array}{l}\text { Procedural } \\
\text { Justice }\end{array}$ & 20.4864 & 4.21873 & .056 & .087 & .095 & -.037 & .090 & $.244^{* *}$ & & & & & \\
\hline 8. & $\begin{array}{l}\text { Interactional } \\
\text { Justice }\end{array}$ & 14.3852 & 3.33592 & .061 & -.076 & -.091 & .048 & .047 & .073 & $.448^{* *}$ & & & & \\
\hline 9. & $\begin{array}{l}\text { Informational } \\
\text { Justice }\end{array}$ & 17.8504 & 3.84064 & .104 & .022 & -.012 & .009 & .008 & $.133^{*}$ & $.496^{* *}$ & $.596^{* *}$ & & & \\
\hline 10. & $\begin{array}{l}\text { Affective } \\
\text { Commitment }\end{array}$ & 20.7821 & 3.85570 & .069 & .053 & .047 & -.038 & .019 & $.224^{* *}$ & $.403^{* *}$ & $.373^{* *}$ & $.474^{* *}$ & & \\
\hline 11. & $\begin{array}{l}\text { Continuance } \\
\text { Commitment }\end{array}$ & 20.9844 & 3.96850 & .043 & -.023 & -.036 & .045 & -.020 & $.234^{* *}$ & $.472^{* *}$ & $.468^{* *}$ & $.598^{* *}$ & $.654^{* *}$ & \\
\hline 12. & $\begin{array}{l}\text { Normative } \\
\text { Commitment }\end{array}$ & 21.0817 & 4.05108 & .044 & .036 & .025 & -.015 & .043 & $.265^{* *}$ & $.512^{* *}$ & $.499^{* * *}$ & $.631^{* *}$ & $.786^{* *}$ & $.784^{* *}$ \\
\hline
\end{tabular}




\section{The Effect of Organizational Justice on Organizational Commitment}

Table 5 presents the values of $\beta$, the values of $F, R^{2}$ and $\Delta R^{2}$. This value is obtained by performing two steps of HRA in each dimension of organizational commitment as dependent variables. In the first step, control variables were regressed on affective commitment as a dependent variable. This analysis conducted to determine the effect of control variables on the dependent variable. By entering control variables, the researcher can ensure that the changes that occur in affective commitment variables are no longer caused by control variables. In this first step, evidence was found that sex, age, tenure, job level, type of organization have no significant effect on affective commitment. With a value of $R^{2}$ is 0.007 indicating that control variables can only explain $0.07 \%$ of the data variance contained in affective commitment. In the second step, each dimensions of organizational justice (distributive, procedural, interational, and information) was included as dependent variables on affective commitment. In this second step, information justice positively affected affective commitment at the level of significance $\rho \leq .001$. Distributive and procedural justice positively affects affective commitment at the level of significance $\rho \leq .005$. While interactional justice only shows an effect on affective commitment at the level of significance $\rho$ $\leq .01$. The value of $F$ is 11.249 , was significant at the level of $\rho \leq, 001$, which proven that the tested regression model was good and could be used further. The value of $R^{2}$ increases to 0.291 , which means that all independent variables (control variables and organizational justice dimensions) accounted for $29.1 \%$ of the data variance contained in affective commitment. There was an increased ability to explain the data variance in affective commitment of $28.4 \%$ by dependent variable $\left(\Delta R^{2}=.284\right)$.

The same procedure was also applied to the continuance commitment dimension. In the first step, the control variables as independent variables were reggressed on the continuance commitment as a dependent variable. In this first step, result obtained that control variables had no significant effect on continuance commitment. With an $R^{2}$ value of .008 suggests that control variables could only explained $.08 \%$ of the data variance in continuance commitment. In the second step, the dimensions of organizational justice (distributive, procedural, intercational, and informational) were included as the dependent variables on continuance commitment after incorporating the control variables. Not much different from the HRA results with affective commitment as the dependent variable, in this second step, informational justice positively affected affective commitment at the level of significance $\rho \leq .001$. Distributive, procedural, and interactional justice positively affected continuance commitment at significance level $\rho \leq .005$. F value of 20,583 was significant at the level of $\rho \leq .001$, which proves that the regression model tested is good and can be used further. The value of $\mathrm{R}^{2}$ increased to .429 , which means that all independent variables (control variables and organizational justice dimensions) were able to explain $42.9 \%$ of the data variationce in continuous commitment. There was an increased ability to explain data variance on continuance commitment by dependent variables of $42.1 \%\left(\Delta \mathrm{R}^{2}=.421\right)$.

Furthermore, the same procedure is also applied to the normative commitment dimension. The control variables as independent variables were reggressed on normative commitment as dependent variable, and obtained evidence that control variables had no significant effect on normative commitment. 
The Multidimensional Constructs of Organizational Justice and Organizational Commitment: Empirical Evidence From Public and Private Organizations in Indonesia

With $\mathrm{R}^{2}$ value of only .004 showed that control variables could only explained $.04 \%$ of data variationce in normative commitment. As in previous HRAs, in the second step, the dimensions of organizational justice (distributive, procedural, intercational, and informational) were included as the dependent variables on continuous commitment after incorporated control variables. HRA results find that distributive, procedural and informational justice affect the normative commitment at the level of significance $\rho \leq .001$. While interactional justice positively affected the normative commitment at the level of significance $\rho \leq .005 . F$ value of 25.913 significant at the level of $\rho \leq .001$, which proved that the tested regression model is good. $R^{2}$ value also better than the results of 2 previous HRAs of .486 , which means that all independent variables (control variables and organizational justice dimensions) were able to explain $48.6 \%$ of the data variance in normative commitment. There was an increased ability to explain the existing data variance on normative commitment by dependent variables of $48.2 \%\left(\Delta \mathrm{R}^{2}=.482\right)$.

Table 5 Result of Hierarchcal Regression Analysis

\begin{tabular}{|c|c|c|c|c|c|c|c|c|c|c|c|c|}
\hline \multirow[b]{3}{*}{ Independent } & \multicolumn{4}{|c|}{ Affective Commitment } & \multicolumn{4}{|c|}{ Continuance Commitment } & \multicolumn{4}{|c|}{ Normative Commitment } \\
\hline & \multicolumn{2}{|c|}{ Step 1} & \multicolumn{2}{|c|}{ Step 2} & \multicolumn{2}{|c|}{ Step 1} & \multicolumn{2}{|c|}{ Step 2} & \multicolumn{2}{|c|}{ Step 1} & \multicolumn{2}{|c|}{ Step 2} \\
\hline & $\boldsymbol{\beta}$ & $\rho$ & $\boldsymbol{\beta}$ & $\rho$ & $\boldsymbol{B}$ & $\rho$ & $\boldsymbol{\beta}$ & $\rho$ & $\beta$ & $\rho$ & $\boldsymbol{B}$ & $\rho$ \\
\hline Gender & .061 & .347 & .021 & .711 & .057 & .375 & .003 & .954 & .035 & .589 & -.022 & .638 \\
\hline Age & .064 & .735 & .002 & .990 & .126 & .503 & .033 & .823 & .072 & .701 & -.024 & .862 \\
\hline Tenure & -.022 & .903 & .078 & .618 & -.138 & .449 & -.009 & .948 & -.065 & .720 & .074 & .580 \\
\hline Job Level & -.019 & .773 & -.021 & .720 & .058 & .387 & .053 & .308 & -.010 & .878 & -.016 & .749 \\
\hline Org. Type & -.011 & .883 & -.055 & .404 & -.036 & .635 & -.076 & .197 & .032 & .672 & -.015 & .788 \\
\hline Distributive & - & - & .151 & .008 & - & - & .133 & .010 & - & - & .157 & .001 \\
\hline Procedural & - & - & .157 & .018 & - & - & .184 & .002 & - & - & .189 & .001 \\
\hline Interactional & - & - & .120 & .087 & - & - & .135 & .032 & - & - & .155 & .009 \\
\hline Informational & - & - & .304 & .000 & - & - & .408 & .000 & - & - & .428 & .000 \\
\hline $\mathrm{F}$ & \multicolumn{2}{|c|}{.358} & \multicolumn{2}{|c|}{$11.249 * * *$} & \multicolumn{2}{|c|}{.400} & \multicolumn{2}{|c|}{$20.583 * * *$} & \multicolumn{2}{|c|}{.201} & \multicolumn{2}{|c|}{$25.913 * * *$} \\
\hline $\mathrm{R}^{2}$ & \multicolumn{2}{|c|}{.007} & \multicolumn{2}{|c|}{.291} & \multicolumn{2}{|c|}{.008} & \multicolumn{2}{|c|}{.429} & \multicolumn{2}{|c|}{.004} & \multicolumn{2}{|c|}{0.486} \\
\hline$\Delta \mathrm{R}^{2}$ & \multicolumn{2}{|c|}{-} & \multicolumn{2}{|c|}{.284} & & & \multicolumn{2}{|c|}{.421} & \multicolumn{2}{|c|}{-} & \multicolumn{2}{|c|}{0.482} \\
\hline
\end{tabular}

\section{DISCUSSION AND CONCLUSION}

The conceptualization and measurement of FFOJ developed by Colquitt (2001) considered as one of the most complete questinnairre to measure organizational justice constructs, and has been tested in various settings (including Dfaz-Gracia et al., 2014; Kovacevic at al., 2013; Shibaoka et al., 2010). This research took part in the stream research that supported Colquitt's (2001) research, by taking the settings of both public and private employees in the province of Bengkulu, Indonesia. The result of factor analysis on 20 items of questions of organizational justice perception variable supports the conceptualization of Colquitt (2001), with 19 items of measurement formed 4 dimensions of organizational justice (procedural 6 items, informational 5 items, interactional and 
distributive each 4 question items). All 4 factors are able to explain $57.47 \%$ variance data of organizational justice.

The item "I have been able to appeal the outcomes arrived at by those procedures" as one of the dimensions of procedural justice, failed to gain empirical support through this study. Possible explanations are related to the generally perceived "appeals process", which is considered as a separate process and requires considerable time, effort, and cost. For public institutions, the denial of an organization's decision may involve the State Administrative Court. The appeal process as well as other judicial processes will involve instruments such as judges, witnesses, trial of courts schedules, etc. So that it can be perceived as a separate process from the other decision-making processes within the organization. That is, the appeal process may be an indicator of justice within the organization in general, but it is not relevant to measure fair or unfair specific procedures in the organization.

The research contexts in various private and public organizations are the main differentiators of this study. The previous studies generally used only one sector, for example service employees (Dfaz-Grasia, et al., 2014), financial organizations (Bin Ismail and Bin Daud, 2016), manufacturing companies (Shibaoka et al., 2010, and Colquitt, 2001), government hospitals (Srivastava, 2015). Thus, it can beconcluded that the measures developed by Colquitt (2001) can generally be used in a variety of contexts, especially in Indonesia. The Indonesian version is also a complement to existing measures, such as the English version (Colquitt, 2001), the Spanish version (Dfaz-Gracia et al., 2014), and the Japanese version (Shibaoka et al., 2010).

The results of this study support the conclusions of previous studies (including Srivastava, 2015, Hassan, 2002; Chen et al., 2015; Rafei-Dehkordi, 2013) about the positive effect of organizational justice on organizational commitment. However, previous tests tend to treat the construct of justice and commitment as a whole, without specifying the effect of each dimension. A more detailed study was conducted by Srivastava (2015) by examining the effect of each of the dimensions of organizational justice, but did not specify the components of organizational commitment separately. This study proved, that if tested separately each dimension of justice and commitment, positive effect also persisted. Among the dimensions of organizational justice, the strongest effect was shown by the dimension of informational justice, while the weakest effect was shown by the interactional justice. From the perspective of organizational commitment, the effect of organizational justice dimensions was most strongly seen in the dimensions of normative commitment.

At the significance level $\rho \leq .005$, interactional justice has no effect on affective commitment. The explanation of the empirical conclusions refers to the substance of the dimension of affective commitment itself. Affective commitment is characterized by a high degree of affection towards the organization. According to Allen \& Meyer (1990), affective commitment refers to the extent to which a person has an emotional attachment, identifies and feels involved in an organization. A person with a high level of affective commitment remains within an organization because he wants it (Meyer et al., 1998). Therefore, the patterns of interaction that occur within the organization may be determinants of whether bound, identified, and engaged in an organization but not very relevant to increase or decrease their love for the organization. 
The Multidimensional Constructs of Organizational Justice and Organizational Commitment: Empirical Evidence From Public and Private Organizations in Indonesia

\section{References}

Allen, N., \& Meyer, J. (1990). The measurement and antecedents of effective, continuance, and normative commitment. Journal of Occupational Psychological, 63: 1-18.

Aquino, K., Griffeth, R. W., Allen, D. G., \& Hom, P. W. (1997). Integrating justice constructs into turnover process: a test of referent cognitions model. Academy of Management Journal, 40 (5): 1208-1227.

Azizi, S., \& Zulkiflee. (2016). The impact of organizational justice on organizational politics at Islamic financial based organization in Malaysia. International Journal of Research in Humanities and Social Studies, 3 (4): 23-29.

Bin Ismail, S. A., \& Bin Daud, Z. (2016). The Impact of Organizational Justice on Organizational Politics at Islamic Financial Based Organization in Malaysia. International Journal of Research in Humanities and Social Studies, 3 (4): 23-29

Chan, M. (2000). Organizational justice theories and landmark cases.International Journal of Organizational Analysis, 8 (1): 68-88

Chen, S., Wu. W., Chang, C., Lin, C., Kung, J., Weng., Lin, Y., \& Lee, S. (2015). Organizational justice, trust, and identification and their effects on organizational commitment in hospital nursing staff. BMC Health Services Research, 15: 1-17

Clugston, M. (2000). The mediating effects of multidimensional commitment on job satisfaction and intent to leave. Journal of Organizational Behavior, 21 (4): $477-486$

Colquitt, J. A. (2001). On dimensionality of organizational justice: a construct validation of a measure. Journal of Applied Psychology, 86 (3): 386-400

Davis, A. L \& Rothstein, H. R. (2006). The effects of the perceived behavioral integrity of managers on employee attitudes: a meta-analysis. Journal of Business Ethics, 67: 407-419

Díaz-Gracia, L., Barbaranelli, C., \& Moreno-Jiménez, B. (2014). Spanish version of Colquitt's organizational justice scale. Psicothema, 26 (4): 538-544.

Folger, R., \& Konovsky, M. A. (1989). Effects of distributive and procedural justice on reaction to pay raise decisions. Academy of Management Journal, 32 (1): $115-130$

Greenberg, J. (2001). Studying organizacional justice cross-culturally: Fundamental challenges.The Internacional Journal of Conflict, 12 (4): 365375

Greenberg, J., and Baron, R.A. (2000). Behavior in Organization: Understanding and Managing the Human Side of Work. Prentice Hall International, New Jersey 
Hair, Jr. J. F, Aderson, R. E., Tatham, R. L., \& Black, W. C. (1998). Multivariate Data Analysis. Prentice-Hall International, Inc. United States

Hassan, A. (2002). Organizational justice as a determinant of organizational commitment and intention to leave. Asian Academy of Management Journal, 7 (2): 55-66

Jawad, M., Raja, S., Abraiz, A., \& Tabassum, T. M. (2012). Role of Organizational justice in organizational commitment with moderating effect of employee work attitudes. Journal of Business and Management, 5 (4):39-45

Ko, J. W., Price, J. 1., \& Mueller, C. W. (1997). Assessment of Meyer and Allen's three-component model of organizational commitment in South Korea. Journal of Applied Psychology, 82 (6): 961-973

Kovačevic, I., Zunic, P., \& Mihailovic, D. (2013). Concept of Organizational Justice in the Context of Academic Achievement. Management Journal for Theory and Practice Management, 69 (): 37-46

Meyer, J. P., Irving, P. G., \& Allen, N. J. (1998). Examination of the combined effects of work values and early work experiences on organizational commitment. Journal of Organizational Behavior, 19: 29-52

Murphy, S. M., Wayne, S. J., Liden, R. C., \& Erdogan, B. (2003). Understanding social loafing: The role of justice perceptions and exchange relationship. Human Relations, 56 (1): 61-84

Pareke, F. Js. (2005). Employee perception of justice in the performance appraisal process: evidence from small businesses in DI Jogjakarta Province, Indonesia. Jurnal Manajemen Prasetya Mulya, Volume 10 Nomor 2, Halaman 68-84

(2004). Hubungan keadilan dan kepuasan dengan keinginan berpindah: peran komitmen organisasional sebagai variable pemediasi, Jurnal Siasat Bisnis, Volume 2, No. 9, halaman 179-195

. (2003). Pengaruh keadilan distributif dan prosedural terhadap komitmen organisasional. Media Ekonomi dan Bisnis, 15 (1): 40-53

Podsakoff, P. M., MacKenzie, S. B., Paine, J. B., \& Bachrach, D. G. (2000). Organizational citizenship behavior: A critical review of the theoretical and empirical literature and suggestions for future research. Journal of Management, 26: 513-563

Rafei-Dehkordi, F., Mohammadi, S., \& Yektayar, M. (2013). Relationship of organizational justice and organizational commitment of the staff in general directorate of youth and sports in Chahar Mahal Va Bakhtiari Province. European Journal of Experimental Biology, (3):696-700

Sekaran, U. (2000). Research Methods for Business: A Skill-Building Approach. John Willey \& Sons, Inc. United Staed of America

Sert, A., Elci, M., Uslu, T., \& Sener, I. (2014). The effects of organizational justice and ethical climate on perceived work related stress. Procedia-Social and Behavioral Sciences , 150: 1187 - 1198 
The Multidimensional Constructs of Organizational Justice and Organizational Commitment: Empirical Evidence From Public and Private Organizations in Indonesia

Shibaoka, M., Takada, M., Watanabe, M., Kojima, R., Kakinuma, M., Tanaka, K., \& Kawakami, N. (2010). Development and validity of the Japanese version of the organizational justice scale. Industrial Health, 48: 66-73

Skitka, L. J., \& Bravo, J. (2005). An Accessible identity approach to understanding Fairness in Organizational Settings. What Motivates Fairness in Organizations? 105-128. Accessed from: www.tigger.uic.edu. on May $20^{\text {th }}$, 2007

Srivastava, U. R. (2015). Multiple dimensions of organizational justice and workrelated outcomes among health-care professionals. American Journal of Industrial and Business Management, 5: 666-685.

Wat, D., \& Shaffer, M. A. (2005). Equity and relationship quality influences on organizational citizenship behaviors: The mediating role of trust in the supervisor and empowerment. Personnel Review, 34 (4): 406-422. 